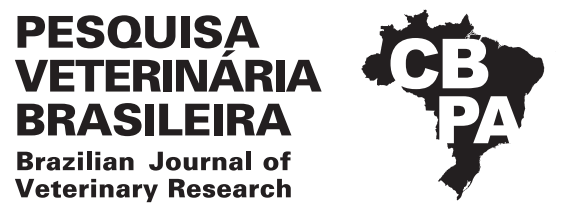

Pesq. Vet. Bras. 39(7):454-459, July 2019 DOI: $10.1590 / 1678-5150-P V B-5913$

Original Article

ISSN 0100-736X (Print)

ISSN 1678-5150 (Online)

\title{
Subgingival bacterial microbiota associated with ovine periodontitis $^{1}$
}

\author{
Natália S. Silva ${ }^{2 *}$ (D) Ana Carolina Borsanelli ${ }^{3}$, Elerson Gaetti-Jardim Júnior ${ }^{4}$, \\ Christiane Marie Schweitzer ${ }^{5}$, José Alcides S. Silveira², Henrique A. Bomjardim², \\ Iveraldo S. Dutra ${ }^{3}$ and José D. Barbosa ${ }^{2}$
}

\begin{abstract}
Silva N.S., Borsanelli A.C., Gaetti-Jardim Júnior E., Schweitzer C.M., Silveira J.A.S., Bomjardim H.A., Dutra I.S. \& Barbosa J.D. 2019. Subgingival bacterial microbiota associated with ovine periodontitis. Pesquisa Veterinária Brasileira 39(7):454-459. Laboratório de Patologia Clínica Veterinária, Faculdade de Medicina Veterinária, Instituto de Medicina Veterinária, Universidade Federal do Pará, Campus de Castanhal, Rodovia BR-316 Km 61, Castanhal, PA 68741-740, Brazil. E-mail: nataliasilvasilveira1@gmail.com

Periodontitis is an inflammatory response in a susceptible host caused by complex microbiota, predominantly composed of Gram-negative anaerobic bacteria. Aiming to characterize the subgingival bacterial microbiota associated with ovine periodontitis, polymerase chain reaction (PCR) was performed in subgingival periodontal pocket samples of 14 sheep with severe periodontitis and in subgingival sulcus biofilm of 14 periodontally healthy sheep in search mainly of Gram-negative and Gram-positive microorganisms considered important periodontopathogens. The most prevalent bacteria in the sheep with periodontal lesions were Tannerella forsythia (78.6\%), Treponema denticola (78.6\%), Fusobacterium nucleatum (64.3\%), and Porphyromonas gingivalis (50\%), whereas in the healthy sheep, F. nucleatum (42.8\%) was the most often detected bacterium. Statistically significant differences were observed for Campylobacter rectus, Enterococcus faecium, Prevotella nigrescens, T. forsythia, and T. denticola $(p<0.05)$ in the sheep with periodontitis in the comparison between groups. Aggregatibacter actinomycetemcomitans, Enterococcus faecalis, and Porphyromonas gulae were not detected in any of the samples analyzed. In conclusion, C. rectus, E. faecium, P. nigrescens, T. forsythia, and T. denticola were associated with severe lesions caused by ovine periodontitis, and $F$. nucleatum was the most prevalent microorganism in the subgengival sulcus biofilm of healthy sheep.
\end{abstract}

INDEX TERMS: Subgingival, bacteria, microbiota, periodontitis, periodontal disease, anaerobic microorganisms, sheep, polymerase chain reaction, bacterioses.

RESUMO.- [Microbiota bacteriana subgengival associada à periodontite ovina.] Periodontite é a resposta inflamatória de

\footnotetext{
${ }^{1}$ Received on September 19, 2018.

Accepted for publication on February 12, 2019.

${ }^{2}$ Faculdade de Medicina Veterinária, Instituto de Medicina Veterinária, Universidade Federal do Pará (UFPA), Campus de Castanhal, Rodovia BR-316 Km 61, Castanhal, PA 68741-740, Brazil. *Corresponding author: nataliasilvasilveira1@gmail.com

${ }^{3}$ Departamento de Apoio, Produção e Saúde Animal, Faculdade de Medicina Veterinária de Araçatuba, Universidade Estadual Paulista "Julio de Mesquita Filho" (Unesp), Rua Clóvis Pestana 793, Jardim Dona Amélia, Araçatuba, SP 16050-680, Brazil.

${ }^{4}$ Departamento de Patologia e Propedêutica Clínica, Faculdade de Odontologia de Araçatuba, Universidade Estadual Paulista "Julio de Mesquita Filho" (Unesp), Rua José Bonifácio 1193, Araçatuba, SP 16015-050.

${ }^{5}$ Departamento de Matemática, Faculdade de Engenharia de Ilha Solteira, Universidade Estadual Paulista "Julio de Mesquita Filho" (Unesp), Alameda Rio de Janeiro 266, Ilha Solteira, SP 15385-000, Brazil.
}

um hospedeiro suscetível causada por complexa microbiota, composta predominantemente por bactérias anaeróbias Gram-negativas. Com o objetivo de caracterizar a microbiota bacteriana subgengival associada à periodontite ovina foi realizada a reação em cadeia da polimerase (PCR) de amostras de biofilme subgengival de 14 ovinos com a enfermidade e 14 ovinos periodontalmente saudáveis, com destaque para micro-organismos Gram-negativos e Gram-positivos considerados importantes periodontopatógenos. As bactérias mais prevalentes em 14 animais com lesões periodontais foram Tannerella forsythia (78,6\%), Treponema denticola $(78,6 \%)$, Fusobacterium nucleatum (64,3\%) e Porphyromonas gingivalis (50\%). Entretanto, nos 14 ovinos sem lesões periodontais, F. nucleatum $(42,8 \%)$ foi a bactéria mais detectada. Associação estatisticamente diferente foi observada para Campylobacter rectus, Enterococcus faecium, Prevotella nigrescens, T. forsythia e T. denticola $(p<0,05)$ nos ovinos 
com periodontite em comparação entre os dois grupos. Aggregatibacter actinomycetemcomitans, Enterococcus faecalis e Porphyromonas gulae não foram detectados em nenhuma das amostras pesquisadas. Conclui-se que $C$. rectus, $E$. faecium, P. nigrescens, T. forsythia e T. denticola estão associados às lesões resultantes da periodontite ovina com manifestação clínica grave e $F$. nucleatum o micro-organismo mais prevalente no biofilme subgengival de animais periodontalmente sadios.

TERMOS DE INDEXAÇÃO: Microbiota, bactéria, subgengival, periodontite, ovinos, doenças periodontais, micro-organismos anaeróbios, reação em cadeia da polimerase, bacterioses.

\section{INTRODUCTION}

Periodontium is the set of tissues that support and protect the teeth comprising the gingiva, periodontal ligament, root cementum, and alveolar bone proper. Periodontitis is a multifactorial infectious disease caused by complex microbiota that interacts with the tissues and cells of a susceptible host, causing the release of a broad array of inflammatory mediators that lead to destruction of the structures that surround and support the dental elements (Holt \& Ebersole 2005, Feng \& Weinberg 2006).

Among several periodontopathogens, bacteria of Socransky Red Complex, namely, Porphyromonas gingivalis, Tannerella forsythia and Treponema denticola, have been considered the main microorganisms causing periodontitis in humans and animals because of their virulence factors and strong association with the disease (Ashimoto et al. 1996, Mayanagi et al. 2004, Feng \& Weinberg 2006). However, recent studies involving metagenomics and metatranscriptomics suggest that the development of periodontitis is associated with more diverse microbiota (Dewhirst et al. 2010, Griffen et al. 2012, Jorth et al. 2014). Thus, the disease results from polymicrobial synergy and dysbiosis, which promote imbalance of the periodontal biofilm associated with homeostasis (Hajishengallis 2015). Dysbiosis is characterized by an imbalance in the relative abundance of species within a microbial community compared with its abundance in health, leading to a change in the host-microorganism ratio sufficient to trigger destructive inflammatory response (Hajishengallis 2014).

In animals raised extensively, high prevalence of periodontitis was described in calves in Brazil in the 1960s, initially associated with the rearing of cattle on newly formed pastures in former native forest and cerrado areas. At the time, it was considered the most important disease in cattle breeding, and limited livestock development in the Southeast and Center-West regions (Döbereiner et al. 1974, 2000). Outbreaks with high prevalence and severity also occurred in pastures replanted in previously endemic areas, which led to serious economic losses to the livestock sector (Dutra et al. 1993, 1999). In conventional microbiological analysis of lesions in bovine periodontitis using traditional methods of anaerobic culture, characterization and identification, it is possible to observe that approximately $80 \%$ of the microbiota of calves associated with periodontitis was composed of black pigmented colonizing bacteria when cultured in blood agar supplemented with hemin and vitamin K (Botteon et al. 1993, Dutra et al. 1999). With the use of molecular techniques such as polymerase chain reaction (PCR), which presents high sensitivity and specificity, several species of the genera Porphyromonas, Prevotella and
Treponema (Borsanelli et al. 2015a, 2015b) were identified in bovine periodontitis, considered as potential pathogens in humans, dogs, cats, sheep, and goats.

Sheep present a clinical condition of periodontitis that may cause premature loss of incisor teeth (Spence et al. 1988). Studies have reported that, in this animal species, the oral microbiota of periodontitis is compatible with that found in human periodontitis (Frisken et al. 1989, Ismaiel et al. 1989, McCourtie et al. 1989, 1990, Duncan et al. 2003). Riggio et al. (2013) evaluated the presence of specific bacterial species in sheep samples with and without periodontitis and emphasized that there were clear differences in the composition of the microbiota between ill and healthy animals. Specimens of two genera of periodontopathogens, Porphyromonas and Prevotella, belonging to the Socransky Red and Orange Complexes, showed close association with lesions of ovine periodontitis (Borsanelli et al. 2017). Likewise, some species of spirochetes of genus Treponema have also been identified in sheep with periodontitis (Borsanelli et al. 2016).

The use of traditional culture methods for detection of oral microorganisms presents operational difficulties, from limitations of biochemical and physiological methods in the precise identification of pathogens to challenges in maintaining the nutritional requirements and oxygen sensitivity of isolates, interfering with the performance of field studies (Ashimoto et al. 1996). In addition, it is estimated that only $3 \%$ of bacteria can be cultured in vitro; $97 \%$ of bacteria cannot be cultured (Davis 2016). In this sense, detection through amplification of the target DNA by PCR is adequate, because it is a highly sensitive and specific technique that enables direct identification of bacteria in biological samples and detection of uncultured microorganisms or of those that are difficult to characterize. Therefore, molecular methods can be used in the detection and evaluation of possible associations between specific microorganisms and periodontitis (Ashimoto et al. 1996).

Silva et al. (2016) reported an outbreak of periodontitis in a sheep herd in the state of Pará, Brazil, with high prevalence and severe clinical signs of periodontitis, weight loss, death, and epidemiological conditions similar to those occurring in episodes of bovine periodontitis. Therefore, the objective of the present study was to identify, through PCR, the presence of specific periodontopathogens in samples of periodontal pocket in animals with periodontitis and of subgingival sulcus biofilm in periodontally healthy sheep.

\section{MATERIALS AND METHODS}

Clinical characterization of periodontitis and sample collection. The study sample was composed of Santa Inês, Dorper and Texel sheep and their crossbreeds aged 5 months to 5 years. Their clinical status was established after extra-and intra-oral examination including periodontal evaluation, verification of attachment loss, tooth mobility, and purulent exudate in the maxillary or mandibular premolar and molar teeth.

Animals were raised under confinement and semi-confinement systems. They were fed Panicum maximum cv. Massai and elephant grass (Pennisetum purpureum) and received mineral mixture and brewery waste supplemented with sodium chloride solution ad libitum.

Samples of purulent exudate of the periodontal pocket of 14 sheep with severe clinical signs of periodontitis were obtained during an outbreak of the disease, reported by Silva et al. (2016), in a property located in the municipality of Benevides, state of Pará, Brazil. Samples 
were collected only from periodontal pockets with depth greater than $5 \mathrm{~mm}$ using sterile swabs, transferred to cryotubes containing ultrapure water, and stored in liquid nitrogen until processing.

Sampling of subgingival sulcus biofilm from periodontally healthy animals was performed in a different herd. The periodontal clinical condition of the animals was classified as healthy when the surrounding gingiva was firm, without bleeding at probing, and when gingival sulcus depth did not exceed $4 \mathrm{~mm}$. Thus, samples of the subgingival biofilm were collected from 14 Sulfolk sheep considered periodontally healthy by the paper cone test according to the procedures described by Gaetti-Jardim et al. (2012). The sheep were raised under an extensive grazing system on Panicum maximum cv. Massai pasture. After the outbreak, this stage of the study was approved by the Ethics Committee on Animal Experimentation (FOA process no. 2015-00280). The paper cones were transferred to cryotubes containing $1 \mathrm{ml}$ sterile ultrapure water and stored at $-80^{\circ} \mathrm{C}$ until DNA extraction.

Bacterial identification by polymerase chain reaction (PCR). DNA extraction was performed in the material collected from the periodontal pocket and subgingival sulcus biofilm using a commercial kit (GenElute Mammalian Genomic DNA Miniprep Kit, Sigma). The search of Aggregatibacter actinomycetemcomitans, Campylobacter rectus, Eikenella corrodens, Enterococcus faecalis, Enterococcus faecium, Fusobacterium nucleatum, Porphyromonas gingivalis, Porphyromonas gulae, Prevotella intermedia, Prevotella nisgrescens, Tannerella forsythia and Treponema denticola was conducted with the use of specific primers (Ashimoto et al. 1996, Gaetti-Jardim et al. 2010, Kato et al. 2011) (Table 1). The specificity of these primers has been demonstrated in the aforementioned literature and can be evaluated at the National Center for Biotechnology Information (NCBI) databases.

Target DNA PCR amplification was performed in $25 \mu \mathrm{L}$ volumes containing $1 \mathrm{X}$ PCR/Mg+2 buffer (Boehring Mannheim, Indianapolis/IN,
USA), $0.2 \mu \mathrm{l}$ of each dNTP (Pharmacia Biotech, Piscataway/NJ, USA), 0.5U Taq DNA polymerase (Invitrogen do Brasil, São Paulo/SP, Brazil), $0.4 \mu \mathrm{L}$ of each primer pair (Invitrogen), and 10ng model. Amplification was performed in thermocycler (Perkin Elmer, GeneAmp PCR System 9700 , Norwalk/CT, USA) programmed at $94^{\circ} \mathrm{C}(5 \mathrm{~min}), 30$ to 40 cycles at $94^{\circ} \mathrm{C}$ ( 30 to $60 \mathrm{~s}$, according to the primers used), specific annealing temperature for each pair of primers, $72^{\circ} \mathrm{C}$ (30 to $60 \mathrm{~s}$ ), followed by a final extension step of $5 \mathrm{~min}$ at $72^{\circ} \mathrm{C}$. PCR amplification products were analyzed by $1 \%$ agarose gel electrophoresis performed in TBE buffer (1M Tris, 0.9M boric acid, 0.01M EDTA, pH 8.4), stained with ethidium bromide $(0.5 \mathrm{mg} / \mathrm{mL})$, and visualized under ultraviolet light (UV Light Transilluminator - Eastman Kodak Co., NY, USA).

As control of the detection procedures, DNA samples from standard strains of the studied microorganisms and clinical samples positive for the target microorganisms were used (Gaetti-Jardim et al. 2010, 2012); ultrapure water was used as negative control.

Statistical analysis. Data were processed and analyzed using the SPSS software. Associations between the groups of animals with and without periodontitis and the bacterial species were verified by the Student's $t$-test and the Spearman's correlation test. Statistical tests underwent the Bonferroni correction with $p$ value adjusted from 0.05 to 0.000003 because 10 microbial species were detected.

\section{RESULTS}

The most prevalent microorganisms in the 14 sheep with severe periodontitis were Tannerella forsythia (78.6\%), Treponema denticola (78.6\%), Fusobacterium nucleatum (64.3\%) and Porphyromonas gingivalis (50\%), whereas in the gingival sulcus of the 14 periodontally healthy sheep, F. nucleatum (42.8\%) was the most often detected microorganism. Aggregatibacter actinomycetemcomitans, Enterococcus faecalis, and Porphyromonas gulae were not detected in any of the samples analyzed (Table 2).

Table 1. Primers used in the polymerase chain reaction (PCR) to identify the bacteria of Socransky Red Complex and other microorganisms present in the subgingival microbiota of sheep with periodontitis

\begin{tabular}{|c|c|c|c|}
\hline Species & Primers $\left(5^{\prime}-3^{\prime}\right)$ & Annealing temperature & Amplicon (bp) \\
\hline Aggregatibacter actinomycetemcomitans & $\begin{array}{l}\text { AAA-CCC-ATC-TCT-GAG-TTC-TTC-TTC } \\
\text { ATG-CCA-ACT-TGA-AGT-TAA-AT }\end{array}$ & 55 & 557 \\
\hline Campylobacter rectus & $\begin{array}{l}\text { TTT-CGG-AGC-GTA-AAC-TCC-TTTT-C } \\
\text { TTT-CTG-CAA-GCA-GAC-ACT-CTT }\end{array}$ & 60 & 598 \\
\hline Eikenella corrodens & $\begin{array}{l}\text { CTA-ATA-CCG-CAT-ACG-TCC-TAA-G } \\
\text { CTA-CTA-AGC-AAT-CAA-GTT-GCC-C }\end{array}$ & 60 & 688 \\
\hline Fusobacterium nucleatum & $\begin{array}{l}\text { ATT-GTG-GCT-AAA-AAT-TAT-AGT-T } \\
\text { ACC-CTC-ACT-TTG-AGG-ATT-ATA-G }\end{array}$ & 40 & 1010 \\
\hline Porphyromonas gulae & $\begin{array}{l}\text { TTG-CTT-GGT-TGC-ATG-ATC-GGG-CT } \\
\text { TAT-TCT-TAC-GGT-ACA-TTC-ACA }\end{array}$ & 60 & 314 \\
\hline Prevotella intermedia & $\begin{array}{l}\text { CGT-GGA-CCA-AAG-ATT-CAT-CGG-T } \\
\text { CTT-TAC-TCC-CCA-ACA-AAA-GCA }\end{array}$ & 55 & 575 \\
\hline Treponema denticola & $\begin{array}{l}\text { TAA-TAC-CGA-ATG-TGC-TCA-TTT-ACA-T } \\
\text { TCA-AAG-AAG-CAT-TCC-CTC-TTC-TTC-TTA }\end{array}$ & 60 & 316 \\
\hline Enterococcus faecalis & $\begin{array}{l}\text { ATC-AAG-TAC-AGT-TAG-TCT } \\
\text { ACG-ATT-CAA-AGC-TAA-CTG }\end{array}$ & 45 & 941 \\
\hline Enterococcus faecium & $\begin{array}{l}\text { TTG-AGG-CAG-ACC-AGA-TTG-ACG } \\
\text { TAT-GAC-AGC-GAC-TCC-GAT-TCC }\end{array}$ & 65 & 658 \\
\hline
\end{tabular}


Table 2. Periodontal pathogens detected in the periodontal pocket of sheep with periodontitis $(n=14)$ and in the subgingival sulcus biofilm of periodontally healthy animals $(n=14)$ by PCR

\begin{tabular}{|c|c|c|c|}
\hline Species & $\begin{array}{c}\text { Periodontal pocket } \\
\mathrm{n}(\%)\end{array}$ & $\begin{array}{c}\text { Subgingival sulcus biofilm } \\
\mathrm{n}(\%)\end{array}$ & $p$ \\
\hline Aggregatibacter actinomycetemcomitans & $0(0.0)$ & $0(0.0)$ & \\
\hline Campylobacter rectus & $6(42.9)$ & $0(0.0)$ & $0.0043^{*}$ \\
\hline Eikenella corrodens & $4(28.6)$ & $1(7.1)$ & 0.1493 \\
\hline Enterococcus faecalis & $0(0.0)$ & $0(0.0)$ & \\
\hline Enterococcus faecium & $6(42.9)$ & $0(0.0)$ & $0.0043^{*}$ \\
\hline Fusobacterium nucleatum & $9(64.3)$ & $6(42.9)$ & 0.2722 \\
\hline Porphyromonas gingivalis & $7(50.0)$ & $3(21.4)$ & 0.1233 \\
\hline Porphyromonas gulae & $0(0.0)$ & $0(0.0)$ & \\
\hline Prevotella intermedia & $3(21.4)$ & $0(0.0)$ & 0.0709 \\
\hline Prevotella loescheii & $1(7.1)$ & $0(0.0)$ & 0.3265 \\
\hline Prevotella nigrescens & $6(42.9)$ & $0(0.0)$ & $0.0043^{*}$ \\
\hline Tannerella forsythia & $11(78.6)$ & $0(0.0)$ & $0.0000^{*}$ \\
\hline Treponema denticola & $11(78.6)$ & $0(0.0)$ & $0.0000^{*}$ \\
\hline
\end{tabular}

Statistical analysis showed positive correlation between Campylobacter rectus, Enterococcus faecium, Prevotella nigrescens, Tannerella forsythia, and Treponema denticola and ovine periodontitis (Table 2).

\section{DISCUSSION}

Dental changes are considered one of the main reasons for the early slaughter of sheep, within their normal breeding period, thus increasing the costs of animal replacement (West 2002). In this context, periodontal disease and excessive tooth wear are the main disturbances affecting the tooth supporting structures and teeth of sheep (West \& Spence 2000). In Brazil, ovine periodontitis has been diagnosed in the North (Silva et al. 2016) and Southeast (Borsanelli et al. 2016, 2017, Agostinho 2017) regions. In the studied herds, this disease was responsible for serious economic losses due to animal weight loss and death (Silva et al. 2016).

Periodontal infection in sheep resulted from an acute process, with severe gingival retraction, attachment loss of the premolar and molar teeth, purulent exudate, bulging of the mandible or maxilla, teeth loss, defects in occlusion, difficulty in rumination, emaciation, and eventual death of animals, clinically characterizing a severe condition (Silva et al. 2016). Despite the growing evidence of primary infectious etiology in periodontal diseases in human medicine and in some animal species, few studies have highlighted the role of specific subgingival microbiota in periodontal disease in ruminants. In the present study, it was possible to associate the occurrence of Tannerella forsythia, Treponema denticola, Prevotella nigrescens, Enterococcus faecium, and Campylobacter rectus with ovine periodontitis.

In ruminants, Tannerella forsythia has been identified in sheep (McCourtie et al. 1989, Duncan et al. 2003, Agostinho 2017), cattle (Borsanelli 2017), and goats (Campello 2017) with periodontitis. This microorganism has been frequently detected in human patients with periodontitis (Cortelli et al. 2005, Foschi et al. 2005, Feng \& Weinberg 2006, Yoo et al. 2007, Gaetti-Jardim et al. 2010, Benrachadi et al. 2012) and, initially, it was believed to be a relatively uncommon species found in the subgingival sulcus biofilm. Presently, it is known that its levels are strongly associated with increased depth of the periodontal pocket. This species is observed in larger number, proportion and prevalence in individuals with periodontitis than in healthy individuals. In this context, this bacterium can also be detected in a larger number of sites with destructive periodontal disease than in healthy sites. In addition, it was detected in larger numbers in progressive active periodontal lesions compared with inactive lesions (Socransky \& Haffajee 2010).

Inclusion of Treponema denticola in the group of microorganisms studied was also based on the evidence that spirochetes play an important role in the etiology of human and animal periodontitis. Among its peculiarities, there is a high number of sites with increased pocket depth and location at the margin of periodontal lesions, which facilitates its adherence to epithelial cells and the invasion of adjacent tissues that should be highlited. Healthy sites show few or none spirochetes and sites with gingival inflammation but without attachment loss, exhibit low to moderate indexes, whereas deep periodontal pockets harbor a large number of these bacteria (Socransky \& Haffajee 2010). T. denticola is considered one of the major periodontopathogens in humans (Mayanagi et al. 2004, Foschi et al. 2005, Feng \& Weinberg 2006, Gaetti-Jardim et al. 2010, Benrachadi et al. 2012), and it has also been identified in periodontal lesions in bovines, sheep and goats (Borsanelli et al. 2015a, 2016, Agostinho 2017, Borsanelli 2017, Campello 2017).

Prevotella nigrescens and Prevotella intermedia cannot be distinguished by conventional culture methods (Ashimoto et al. 1996). In the present study, it was possible to verify the presence of both species in the periodontal lesions of sheep, but only P. nigrescens showed significant association with the disease. $P$. nigrescens has been identified in bovines and sheep with periodontitis (Borsanelli et al. 2015a, 2017), and is frequently detected in the subgingival sulcus biofilm of healthy human patients with periodontitis (Mayanagi et al. 2004).

In human periodontitis, Campylobacter rectus is present in larger numbers in diseased sites (Doğan et al. 2003) with active periodontal destruction (Rams et al. 1993) and in individuals with severe periodontitis (Gajardo et al. 2005). In livestock, $C$. rectus has been identified in sheep, goats and 
cattle with periodontitis (Agostinho 2017, Borsanelli 2017 Campello 2017). This microorganism has also been identified in dogs with periodontitis (Nishiyama et al. 2007, Hirai et al. 2013) and in robust capuchin monkeys with gingivitis and periodontitis (Gaetti-Jardim et al. 2012).

In humans, detection of enteric bacteria in periodontal pockets seems to be inversely proportional to the presence of anaerobic periodontopathogens (Botero et al. 2007); however, the opposite was observed in the present study, and Enterococcus faecium showed association with ovine periodontal lesions.

Considering the limited number of primers used in the present study, other microorganisms were surely present in the subgingival microbiota of sheep with periodontitis. However, the presence of periodontally pathogenic species, such as Tannerella forsythia, Treponema denticola and Prevotella nigrescens, brings important elements to elucidate the polymicrobial and multifactorial etiology of ovine periodontitis and understand the consequences of this infectious process.

Direct examination of material from the periodontal lesions of the sheep through PCR, with its recognized sensitivity and specificity, enabled detection of microorganisms of complex culture, such as T. denticola, and avoided the use of laborious and not always successful steps in the isolation of non-sporulated anaerobic microorganisms (Socransky \& Haffajee 2010). In the same context, it was possible to observe absence of Enterococcus faecalis in ovine microbiota, as well as absence of two of the most important human periodontopathogens, Aggregatibacter actinomycetemcomitans and Porphyromonas gulae, associated with periodontitis in dogs (Dahlén et al. 2012).

The taxonomic changes that have occurred in several periodontopathogens and the current methods for detecting bacteria in the subgingival microbiota hinder the accurate establishment of parallels between the findings of the present study and the species isolated from the periodontal pocket in calves with "cara inchada" (Blobel et al. 1984, Dutra et al. 1986, Botteon et al. 1993). Although a preliminary comparative analysis of ovine periodontitis can establish points in common with microbiological studies, the clinical-pathological and epidemiological situation of this outbreak of periodontitis in sheep in addition to the presence of periodontopathogens resemble that occurred in bovine periodontitis (Dutra et al. 1999, Döbereiner et al. 2000). It should be emphasized that the present study describes the occurrence of microorganisms with periodontal pathogenic potential, using a qualitative molecular technique that met the purposes of the study and added objective complementary information on the possible causes of ovine periodontitis. Thus, this is an important step in elucidating the causal factors associated with the disease, which, as a multifactorial, infectious, polymicrobial disease associated with complex dental biofilm, should fill the Socransky's postulate, and not the classic Koch's postulates.

\section{CONCLUSIONS}

Campylobacter rectus, Enterococcus faecium, Prevotella nigrescens, Tannerella forsythia and Treponema denticola are associated with lesions resulting from ovine periodontitis with severe clinical manifestation.

Fusobacterium nucleatum was the most prevalent microorganism in the subgingival sulcus biofilm of periodontally healthy sheep.
Acknowledgments.- The authors would like to thank the "Pró-Reitoria de Pesquisa e Pós-Graduação" of the "Universidade Federal do Pará" (Edital 01/2019 - PROPESP/PAPQ) for their financial support.

Conflict of interest statement.- The authors have no competing interests.

\section{REFERENCES}

Agostinho S.D. 2017. Periodontite e desgaste dentário em ovinos. Doctoral Dissertation, Faculdade de Ciências Agrárias e Veterinárias, Universidade Estadual Paulista, Jaboticabal. 78p.

Ashimoto A., Chen C., Bakker I. \& Slots J. 1996. Polymerase chain reaction detection of 8 putative periodontal pathogens in subgingival plaque of gingivitis and advanced periodontitis lesions. Oral Microbiol. Immunol. 11(4):266-273. <http://dx.doi.org/10.1111/j.1399-302X.1996.tb00180. $\mathrm{x}><$ PMid:9002880>

Benrachadi L., Bouziane A., Azziman Z., Bouziane-Ouartini F. \& Ennibi O. 2012. Screening for periodontopathogenic bacteria in severe chronic periodontitis in a Moroccan population. Med. Mal. Infect. 42(12):599-602. <http://dx.doi.org/10.1016/j.medmal.2012.10.003> <PMid:23141872>

Blobel H., Döbereiner J., Lima F.G.F. \& Rosa I.V. 1984. Bacterial isolations from "cara inchada" lesions of cattle. Pesq. Vet. Bras. 4(2):73-77.

Borsanelli A.C. 2017. Genotipagem de bactérias anaeróbias associadas às lesões da periodontite bovina. Doctoral Dissertation, Faculdade de Ciências Agrárias e Veterinárias, Universidade Estadual Paulista, Jaboticabal. 121p.

Borsanelli A.C., Gaetti-Jardim Jr E., Döbereiner J. \& Dutra I.S. 2015a. Treponema denticola in microflora of bovine periodontitis. Pesq. Vet. Bras. 35(3):237240. <http://dx.doi.org/10.1590/S0100-736X2015000300005>

Borsanelli A.C., Gaetti-Jardim Jr E., Schweitzer C.M., Döbereiner J. \& Dutra I.S. 2015b. Presence of Porphyromonas and Prevotella species in the oral microflora of cattle with periodontitis. Pesq. Vet. Bras. 35(10):829-834. <http://dx.doi.org/10.1590/S0100-736X2015001000002>

Borsanelli A.C., Ramos T.N.M., Gaetti-Jardim Jr E., Schweitzer C.M. \& Dutra I.S. 2016. Treponema species in the subgingival microflora of ovine periodontitis. Vet. Rec. 180(6):150. <PMid:27856942>

Borsanelli A.C., Gaetti-Jardim Jr E., Schweitzer C.M., Viora L., Busin V., Riggio M.P. \& Dutra I.S. 2017. Black-pigmented anaerobic bacteria associated with ovine periodontitis. Vet. Microbiol. 203:271-274. <http://dx.doi. org/10.1016/j.vetmic.2017.03.032> <PMid:28619155>

Botero J.E., Arce R.M., Escudero M., Betancourth M., Jaramillo A. \& Contreras A. 2007. Frequency of detection of periodontopathic and superinfecting bacteria in HIV-positive patients with periodontitis. J. Int. Acad. Periodontol. 9(1):13-18. <PMid:17274235>

Botteon R.M., Dutra I.S., Döbereiner J. \& Blobel H. 1993. Caracterização de bactérias anaeróbias isoladas de lesões peridentárias da "cara inchada" dos bovinos. Pesq. Vet. Bras. 13(3/4):51-55

Campello P. 2017. Periodontite e desgaste dentário em cabras leiteiras. Doctoral Dissertation, Faculdade de Ciências Agrárias e Veterinárias, Universidade Estadual Paulista, Jaboticabal. 101p.

Cortelli J.R., Cortelli S.C., Jordan S., Haraszthy V.I. \& Zambon J.J. 2005. Prevalence of periodontal pathogens in Brazilians with agressive or chronic periodontitis. J. Clin. Periodontol. 32(8):860-866. <http://dx.doi. org/10.1111/j.1600-051X.2005.00777.X><PMid:15998269>

Dahlén G., Charalampakis G., Abrahamsson I., Bengtsson L. \& Falsen E. 2012. Predominant bacterial species in subgingival plaque in dogs. J. Periodontal. Res. 47(3):354-364. <http://dx.doi.org/10.1111/j.1600-0765.2011.01440. $\mathrm{x}><$ PMid:22181039>

Davis E.M. 2016. Gene sequence analyses of the healthy oral microbiome in humans and companion animals: a comparative review. J. Vet. Dent. 33(2):97107. <http://dx.doi.org/10.1177/0898756416657239><PMid:28326980>

Dewhirst F.E., Chen T., Izard J., Paster B.J., Tanner A.C.R., Yu W., Lakshmanan A. \& Wade W.G. 2010. The human oral microbiome. J. Bacteriol. 192(19):50025017. <http://dx.doi.org/10.1128/JB.00542-10> <PMid:20656903> 
Döbereiner J., Inada T. \& Tokarnia C.H. 1974. “Cara inchada”, doença peridentária em bovinos. Pesq. Agropec. Bras. 9:63-85.

Döbereiner J., Dutra I.S., Rosa I.V. \& Blobel H. 2000. Cara inchada of cattle, an infectious, apparently soil antibiotics-dependant periodontitis in Brazil. Pesq. Vet. Bras. 20 (2):47-64. <http://dx.doi.org/10.1590/S0100736X2000000200001>

Doğan B., Antinheimo J., Cetiner D., Bodur A., Emingil G., Buduneli E., Uygur C., Firatli E., Lakio L. \& Asikainen S. 2003. Subgingival microflora in Turkish patients with periodontitis. J. Periodontol. 74(6):803-814.<http://dx.doi. org/10.1902/jop.2003.74.6.803> <PMid:12886990>

Duncan W.J., Persson G.R., Sims T.J., Braham P., Pack A.R.C. \& Page R.C. 2003. Ovine periodontitis as a potential model for periodontal studies. Crosssectional analysis of clinical, microbiological, and serum immunological parameters. J. Clin. Periodontol. 30(1):63-72. <http://dx.doi.org/10.1034/ j.1600-051X.2003.10104.X><PMid:12702113>

Dutra I.S., Kanoe M. \& Blobel H. 1986. Atividades enzimáticas e endotóxicas de bactérias isoladas de lesões peridentárias da "cara inchada" dos bovinos. Pesq. Vet. Bras. 6(2):59-63.

Dutra I.S., Matsumoto T. \& Döbereiner J. 1993. Surtos de periodontite em bezerros ("cara inchada") associados ao manejo do solo. Pesq. Vet. Bras. 13(1/2):1-4

Dutra I.S., Botteon R.C.M. \& Döbereiner J. 1999. Modificação da microbiota associada às lesões peridentárias da "cara inchada" em bezerros transferidos para área indene. Pesq. Vet. Bras. 20(2):71-74.<http://dx.doi.org/10.1590/ S0100-736X2000000200003>

Feng Z. \& Weinberg A. 2006. Role of bacteria in health and disease of periodontal tissues. Periodontol. 2000 40(1):50-76. <http://dx.doi. org/10.1111/j.1600-0757.2005.00148.x> <PMid:16398685>

Foschi F., Cavrini F., Montebugnoli L., Stashenko P., Sambri V. \& Prati C. 2005. Detection of bacteria in endodontic samples by polymerase chain reaction assays and association with defined clinical signs in Italian patients. Oral Microbiol. Immunol. 20(5):289-295. <http://dx.doi.org/10.1111/j.1399302X.2005.00227.X><PMid:16101964>

Frisken K.W., Laws A.J., Tagg J.R. \& Orr M.B. 1989. Environmental influences on the progression of clinical and microbiological parameters of sheep periodontal disease. Res. Vet. Sci. 46(2):147-152.<http://dx.doi.org/10.1016/ S0034-5288(18)31137-8><PMid:2784861>

Gaetti-Jardim Jr E., Fardin A.C., Gaetti-Jardim E.C., Castro A.L., Schweitzer C.M. \& Avila-Campos M.J. 2010. Microbiota associated with chronic osteomyelitis of the jaws. Braz. J. Microbiol. 41(4):1056-1064. <http:// dx.doi.org/10.1590/S1517-83822010000400025> <PMid:24031586>

Gaetti-Jardim Jr E., Monti L.M., Ciesielski F.I.N., Gaetti-Jardim E.C., Okamoto A.C., Schweitzer C.M. \& Avila-Campos M.J. 2012. Subgingival microbiota from Cebus apella (capuchin monkey) with different periodontal conditions. Anaerobe 18(3):263-269. <http://dx.doi.org/10.1016/j.anaerobe.2012.02.002> $<$ PMid:22710412>

Gajardo M., Silva N., Gómez L., León R., Parra B., Contreras A. \& Gamonal J. 2005. Prevalence of periodontopathic bacteria in aggressive periodontitis patients in a Chilean population. J. Periodontol. 76(2):289-294. <http:// dx.doi.org/10.1902/jop.2005.76.2.289> <PMid:15974855>

Griffen A.L., Beall C.J., Campbell J.H., Firestone N.D., Kumar P.S., Yang Z.K., Podar M. \& Leys E.J. 2012. Distinct and complex bacterial profiles in human periodontitis and health revealed by $16 \mathrm{~S}$ pyrosequencing. Microbiol. Ecol. 6(6):1176-1185. <PMid:22170420>

Hajishengallis G. 2014. Immunomicrobial pathogenesis of periodontitis: keystones, pathobionts, and host response. Trends Immunol. 35(1):3-11. <http://dx.doi.org/10.1016/j.it.2013.09.001><PMid:24269668>

Hajishengallis G. 2015. Periodontitis: from microbial immune subversion to systemic inflammation. Nat. Rev. Immunol. 15(1):30-44. <http://dx.doi. org/10.1038/nri3785> <PMid:25534621>

Hirai N., Shirai M., Kato Y., Murakami M., Nomura R., Yamasaki Y., Takahashi S., Kondo C., Matsumoto-Nakano M., Nakano K. \& Asai F. 2013. Correlation of age with distribution of periodontitis-related bacteria in Japanese dogs.
J. Vet. Med. Sci. 75(7):999-1001. <http://dx.doi.org/10.1292/jvms.130041> <PMid:23485527>

Holt S.C. \& Ebersole J.L. 2005. Porphyromonas gingivalis, Treponema denticola and Tannerella forsythia: the 'red complex', a prototype polybacterial pathogenic consortium in periodontitis. Periodontol. 2000 38(1):72-122. <http://dx.doi.org/10.1111/j.1600-0757.2005.00113.x><PMid:15853938>

Ismaiel M.O., Greenman J., Morgan K., Glover M.G., Rees A.S. \& Scully C. 1989. Periodontitis in sheep: a model for human periodontal disease. J. Periodontol.60(5):279-284. <http://dx.doi.org/10.1902/jop.1989.60.5.279> $<$ PMid:2738834>

Jorth P., Turner K.H., Gumus P., Nizam N., Buduneli N. \& Whiteley M. 2014 Metatranscriptomics of the human oral microbiome during health and disease. mBio 5(2):1-10. <http://dx.doi.org/10.1128/mBio.01012-14> <PMid:24692635>

Kato Y., Shirai M., Murakami M., Mizusawa T., Hagimoto A., Wada K., Nomura R., Nakano K., Ooshima T. \& Asai F. 2011. Molecular detection of human periodontal pathogens in oral swab specimens from dogs in Japan. J. Vet Dent. 28(2):84-89. <http://dx.doi.org/10.1177/089875641102800204> $<$ PMid:21916371>

Mayanagi G., Sato T., Shimauchi H. \& Takahashi N. 2004. Detection frequency of periodontitis-associated bacteria by polymerase chain reaction in subgingival and supragingival plaque of periodontitis and healthy subjects. Oral Microbiol. Immunol. 19(6):379-385. <http://dx.doi.org/10.1111/j.1399302x.2004.00172.x><PMid:15491463>

McCourtie J., Poxton I.R., Spence J.A. \& Aitchison G.U. 1989. Preliminary study of the anaerobic bacteria isolated from subgingival plaque from sheep. Vet. Microbiol. 21(2):139-146. <http://dx.doi.org/10.1016/03781135(89)90026-6><PMid:2609499>

McCourtie J., Poxton I.R., Brown R., Whittaker C.R., Spence J.A. \& Aitchison G.U. 1990. A longitudinal study of the cultivable subgingival bacteria isolated from sheep during the development of broken mouth periodontitis. J. Med. Microbiol. 31(4):275-283. <http://dx.doi.org/10.1099/00222615-31-4275><PMid:2182879>

Nishiyama S.A.B., Senhorinho G.N.A., Gioso M.A. \& Avila-Campos M.J. 2007. Detection of putative periodontal pathogens in subgingival specimens of dogs. Braz. J. Microbiol. 38(1):23-28. <http://dx.doi.org/10.1590/S151783822007000100006>

Rams T.E., Feik D. \& Slots J. 1993. Campylobacter rectus in human periodontitis. Oral Microbiol. Immunol. 8(4):230-235. <http://dx.doi.org/10.1111/j.1399302X.1993.tb00565.X $><$ PMid:8247610>

Riggio M.P., Jonsson N. \& Bennett D. 2013. Culture-independent identification of bacteria associated with ovine 'broken mouth' periodontitis. Vet. Microbiol. 166(3/4):664-669. <http://dx.doi.org/10.1016/j.vetmic.2013.06.034> $<$ PMid:23928119>

Silva N.S., Silveira J.A.S., Lima D.H.S., Bomjardim H.A., Brito M.F., Borsanelli A.C., Dutra I.S. \& Barbosa J.D. 2016. Epidemiological, clinical and pathological aspects of an outbreak of periodontitis in sheep. Pesq. Vet. Bras. 36(11):1075 1080. <http://dx.doi.org/10.1590/s0100-736x2016001100003>

Socransky S.S. \& Haffajee A.D. 2010. Infecções periodontais, p.197-254. In Lindhe J., Lang N.P. \& Karring T. (Eds), Tratado de Periodontia Clínica e Implantologia Oral. $5^{\underline{a}}$ ed. Guanabara Koogan, Rio de Janeiro.

Spence J.A., Aitchison G.U. \& Fraser J. 1988. Development of periodontal disease in a single flock of sheep: clinical signs, morphology of subgingival plaque and influence of antimicrobial agents. Res. Vet. Sci. 45(3):324-331. <http://dx.doi.org/10.1016/S0034-5288(18)30959$7><$ PMid:3212280>

West D.M. 2002. Dental disease of sheep. New Zeal. Vet. J. 50(3):102-104 <https://doi.org/10.1080/00480169.2002.36282>

West D.M. \& Spence J.A. 2000. Diseases of the oral cavity, p.125-131. In: Martin W.B. \& Aiken I.D. (Eds), Diseases of Sheep. 3rd ed. Blackwell Science, London.

Yoo J.Y., Kim H.C., Zhu W., Kim S.M., Sabet M., Handfield M., Hillman J., ProgulskeFox A. \& Lee S. 2007. Identification of Tannerella forsythia antigens specifically expressed in patients with periodontal disease. FEMS Microbiol. Lett. 275(2):344-352. <http://dx.doi.org/10.1111/j.1574-6968.2007.00906. x><PMid:17868359> 